\title{
Banking Competition and Stability: Comprehensive Literature Review
}

\author{
Bekmurodova Go'zal Adhamovna \\ Senior Researcher, Tashkent State University of Economics, Tashkent, Uzbekistan
}

\begin{abstract}
The main aim of this paper is to define and propose the determining variables of banking competition by reviewing the literature on bank competition. Extensive review of the literature led to the identification of main variables that can be used to measure banking competition. They include market structure variables, contestability variables; inter industry variables, institutional variables and macro-economic condition variables. The exploration of these important variables began by reviewing and analysing two main schools of thought on bank competition. They include competition fragility and competition stability theories. The analysis of schools of though is followed by measures of competition such as HHI, Lerner index, Boone indicator and Z-score. The implications of this study are targeted for bank executives and government officials who are mainly concerned with improving the social well-fare of stakeholders.
\end{abstract}

Keywords: Bank competition, Boone indicator, Lerner index, HHI, Z-score, Bank competition-fragility theory, Bank competition-stability theory

\section{Introduction}

In recent years, scientists have witnessed the strong evolution of arguments and research interests in the area of banking competition. Many scholars and prominent experts in the banking sphere expressed various opinions regarding the critical importance of competition in the banking sector. It is said that large banks that have monopolistic power in the market charge higher loan interests from the firms. As a result, most of the businesses avoid undertaking risky business projects due to the high loan interests. This will have negative influence on the operations of credit market and financial stability. Moreover, due to the influence of high lending rates, most financial institutions do not stimulate their research and development activities which will later affect to the creation of new technologies and products. Therefore, soundness of competition in the banking sector is of great importance. Many banks, financial institutes and insurance companies that are competing with each other are believed to reduce the price of their products and services. Moreover, competition is believed to motivate and stimulate innovative actions by increasing the efficiency of banks.

An enormous amount of empirical and theoretical studies have been conducted in order to analyze and understand the certain variables of banks. Despite the significant amount of papers that propose different models to explain the competitive nature of banks, most of the papers lack to provide clear evidence to explain determining factors of competition. The importance of identifying these factors can be highlighted in terms of their benefit for government officials and financial managers to formulate necessary actions and plans.

Close consideration of previous investigations regarding measuring bank competition shows that average size of banks, number of banks and bank concentration were regarded as the determining factors in relation to bank competition (Abedifar, et al, 2014; Milbourn, et al, 1999; Weill, 2013). However, latest advances in the technology, precisely, recent innovations in the case of information communication technologies have fostered the process of competition by providing necessary means for several banks to ensure their strategic position in the market. Therefore, most scholars argue about the potential determinants of competition. Many scholars explain that threat of new entrants has shown the greater influence to the extent of competition (Allen, et al, 2004, Laeven, et al, 2013; Jeon, and Lim, 2013 
Andrievskaya and Semenov, 2016). The main aim of this paper is to define and propose the determining variables of banking competition by reviewing the literature on bank competition.

\section{Theoretical Background}

\subsection{Schools of thought on bank competition}

Most scholars have been discussing the relationship between banking rivalry and financial stability for the last two decades. Most of these discussions went viral especially after global financial crisis of 2007. Therefore, competition in banking sector has been one the most debated issues of all time. Previous literature by Koetter et al, (2012) provides evidence that there are two mostly argued theories regarding banking competition and its stability. The first theory is known as competition fragility theory. This theory states the negative correlation between banking competition and its stability. This can be explained by the fact that too intense rivalry among banks has negative influence on market power and margins of profit. This, in turn, leads banks to make risky decisions. Another school of thought of banking literature suggests competition stability theory which emphasizes greater banking stability as the result of increased competition among banks. The explanation for this theory can be provided in terms of interest rates which decrease as a result of increasing competition. As a result of reduced moral hazard and adverse selection problems, banks start to issue more loans by decreasing default rates of loans which ensures the stability of banks Koetter et al, (2012).

The study conducted by (2015) analyzed the influence of banking competition on Turkish banking sector during the period of 2002-2012. In order to measure the competitiveness of banks, Boone indicator and Lerner index were used. In order to measure the stability, researchers used non-performing loan ratios and Z-score. Results of the study showed negative correlation between bank competition and non-performing loan ratio. However, positive link has been identified between bank competition and Z-score. The results of this research provide support for bank-fragility theory. According to his theory, banks risk taking incentives are influenced by increasing bank competition. It is explained in the case of perfect competition where the profit of banks will be zero and investments opportunities offered by banks will be reasonable for many clients since banks will not be afraid of losing anything (Keeley, 1990).

One more theory related to bank competition proposed by Keeley (1990) can be used to explain the bank competitiveness theory. In other words, it is believed that less concentrated banking markets are main culprits of financial crises. In this case, it is important to mention the franchise value of banks. Franchise value controls the activities of the banks by reducing the number of risk taking bank activities. Banks with high rates of risk taking is believed to be involved in insolvency. Therefore, competition fragility theory mentions that as a result of excess competition, franchise value of banks starts eroding leading banks to more risk taking activities. In imperfect competition, the cases of bankruptcy can be eliminated in the presence of high market power (Leon, 2015; Beck, 2013; Milbourn, 1999).

Another famous theory in the banking literature known as competition stability theory assumes positive link between bank competition and stability. It is stated that less competition results in high interest rates. High rates of interest can lead to moral hazard problem by increasing non-performing loan ratio of banks. Most of the previous papers also considered the relationship between the banks and borrowers. The research by Boyd and De Nicolo (2005) proposed the theoretical model mentioning that borrowers are able to identify the riskiness of projects using the case of loan rates. The study conducted by Boyd and De Nicole (2005) provides the support for competition-stability theory. In other words, it implies that less competition in banking sector results in high interest rates charged by banks. Therefore, it is supposed that less banking competition with high interest rates can lead to the bankruptcy of the borrowing firm.

\subsection{Measures of bank competition}

Many scholars argued about the measures which can be used to determine and explain the competitive nature of banks. The review of previous literature shows the increasing importance of the following measures that are extensively used to measure bank competition. The following table provides the description of the following measures including HHI, Lerner index, Boone indicator, Z-score and H-statistic. 
Table 1: Bank Competition measurement tools and their description

\begin{tabular}{|c|l|}
\hline Measure of bank competition & \multicolumn{1}{|c|}{ Description } \\
\hline HHI & $\begin{array}{l}\text { The Herfindahl-Hirschman index (HHI) is used to } \\
\text { measure market concentration. In monopoly markets, } \\
\text { market concentration is regarded as being high; } \\
\text { therefore, high concentration implies low competition. } \\
\text { In the case of perfect competition, HHI index will be } \\
\text { quite low indicating high levels of competition. }\end{array}$ \\
\hline Lerner index & $\begin{array}{l}\text { This index is used to measure the power of market. } \\
\text { Shows the difference between output pricing and mark } \\
\text { up cost. High Lerner index implies the decreasing } \\
\text { competitive force in banking industry. }\end{array}$ \\
\hline Boone indicator & $\begin{array}{l}\text { Determines level of competition based on the profit } \\
\text { efficiency of banks. Calculated by taking profit } \\
\text { elasticity in relation to mark up cost. High Boone } \\
\text { indicator implies the decreasing competitive power in } \\
\text { financial market }\end{array}$ \\
\hline Z-score & $\begin{array}{l}\text { Z-score is used to manage financial health and } \\
\text { stability of banks in the market. }\end{array}$ \\
\hline H-statistic & $\begin{array}{l}\text { Similar to ANOVA test which shows whether there is } \\
\text { a statistically significant difference in the group means } \\
\text { of more than two groups }\end{array}$ \\
\hline
\end{tabular}

Previous literature suggests that HHI, Lerner index and $\mathrm{H}$-statistic are regarded as the main measurements used in empirical studies to measure bank competitiveness. The study by Bolt and Humphrey (2015) used three measures of banking competition including HHI, Lerner Index and H-statistic. This may also imply that negative correlation among these three measures. For instance, when HHI index shows that competition in banking sector is strong, the outcomes of Lerner index and H-statistic shows the different outcome. Results of the study by Bolt and Humphrey (2015) with the sample of total 2655 banks and 382 financial institutions reported weak relationship among three measures of competition in relation to each other, stating that banks with the highest loan rates are the least competitive. One explanation for this is that three measures of competition measure bank competitiveness differently from each other. That is to say that result of HHI index is uncorrelated to the outcomes of Lerner index and H-statistic. Another study of Bolt and Humphrey (2015) uses "competition efficiency" theory, with three measures of banking competition including HHI, Lerner index and H-statistic. Results of the paper suggest evidence which supports the argument that HHI, Lerner index and $\mathrm{H}$-statistic are uncorrelated with each other and US banks which has the lowest rate for consumer loans are considered to be the highly competitive. Moreover, Boone indicator and Lerner index mostly used bank competition measures have strong negative relationship with non-performing loan ratio of banks (Bolt and Humphrey, 2015). Therefore, based on the available analysis, it can be stated that bank fragility theory has been supported.

\subsection{Potential determinants of competition}

\subsubsection{Market structure variables}

Many scholars argued and proposed different variables that can be used to explain banking competition. According to Biiker, et al (2007), the following variables are considered to play important role in defining the potential role of bank competition. They include market structure variables, contestability variables, inter-industry variables and institutional variables, and macro-economic variables.

The review of the previous literature shows that market structure variables were considered to be one of the most important factors in defining the extent of importance of bank competition. According to Biiker, et al (2007), market structure variables can be divided into different sub categories and they include bank concentration ratios, number of banks, and ownership of foreign banks. Numerous studies used the market structure variables in order to identify their impact on bank competition (Tabacco, 2013; Bikker, 2007, Jappelli, 1993, Braunstein, et al, 2002). Five bank concentration ratios is one of the widely used ratios to determine bank concentration. In other words, it is calculated considering total market share of the largest five banks in a specific country in relation to their total assets. Number of 
banks is also regarded as one of the variables which explain market structure. However, bank concentration ratio has shown negative relationship with number of banks which can be considered as one of the shortcomings of market structure variables. Main underlying explanation of ownership of foreign banks is the percentage of assets owned by foreign banks in total banking system as foreign banks are believed to perform differently from local banks. Moreover, state owned banks can also be regarded as the sub component of market structure variables. State owned banks represent the fraction of $50 \%$ or more asset ownership by government in relation to total banking system.

\subsubsection{Contestability variables}

Contestability is considered as the main factor influencing bank competitiveness. Contestability is described as the form of the market characterized by the freedom of entry and freedom of exit. Recent study conducted by Saez and Shi (2004) using the bank data from 50 countries reported that contestability had greater influence on bank competition compared to bank concentration and other market structure variables. In explaining the contestability, it is important to mention variables that contribute to its presence. Researchers including Leon, F (2015) reported that competition of banking segments and freedom of entry to bank market were considered as the main variables ensuring the presence of contestability in banking sector. In this regard, the existence of these factors such as rivalry among banks and freedom of entry is mainly related to the operations of large banks. Turk Arriss (2009) claimed that contestability is effective in identifying the competitive nature of banks in the Middle East by increasing the chances of foreign bank entry and simplifying the operations by eliminating activity restrictions. Bikker et al (2007) identified the number of variables that make up contestability including activity restrictions and restrictions on financial conglomerate.

Activity restriction variable is reported to vary from zero to twelve. Zero indicates the least restriction of activities while twelve stands for highest restriction of activities. The activity restrictions are understood in terms of restriction set for insurance, security and real estate activities. Similar to activity restrictions, financial conglomerate measure also ranges from zero to twelve, zero indicating the least conglomerate set for financial activity while twelve may imply the highest restrictions.

The financial conglomerate can be explained in terms of owning non-financial resources controlled by the bank. Mirzaei (2014) also proposed additional variables to explain the importance of contestability factors. These variables include limit on foreign bank, entry requirement and fraction denied. With the values ranging from 0 to 4 , limit on foreign bank indicates the extent regarding how much of the foreign bank assets can be owned by domestic banks and how much of the assets of domestic bank can be owned by foreign banks.

Limit on foreign bank variable also explains through which forms of strategy such as acquisition, branch and subsidiary foreign banks can enter the bank market. Another variable proposed by Mirzaei (2014) is entry requirement which explains the importance of ban licence that is necessary to obtain in order to enter the bank industry. In other words, entry requirements variable is concerned whether foreign banks need to possess draft by laws and organizational charters in order to obtain ban king license. The last but not least sub variable of contestability is fraction denied which shows the percentage of application that has been rejected to enter bank industry.

\subsubsection{Inter industry variables}

Variables that constitute inter industry variables include capital markets and insurance firms. Many scholars have found the significant impact of inter industry variables in explaining the nature of bank competitiveness. Precisely, the critical importance of inter industry variables have been reported in the case of advanced banking systems where they played dominant role in explaining the nature of competition (Mirzaei,2014). Capital markets are considered as market capitalizations of stock which represent the largest proportion of GDP. Market capitalization is calculated by multiplying the outstanding shares of company to market price of one share. Insurance firms represent the amount of life and non-life volume of non-financial sectors that constitute the GDP other than banking. Most of the scholars in the area of banking including (Delis, 2012; Tabacco, 2013; Mirzaei,2014 reported that inter industry variables such as market capitalization was mainly positively related to competition in developed countries whereas its impact on competition was not so noticeable in developing countries

\subsubsection{Institutional variables}

Institutional variables include the following sub variables such as financial freedom, property rights and KKZ index. Property right indicate the number of laws adopted by the government for the purpose of protecting property rights of 
individuals and organization. This variable also shows the extent of support by the government to ensure fulfilment of the criteria's mentioned in those laws. The measure of the current variable varies from 0 to 100 . Higher the measure indicates higher the protection of property. KKZ index is an average indicator of the quality of political stability, regulatory, control of corruption and etc. The higher is the value of KKZ the higher the institutional quality. Institutional factors such as property right and $\mathrm{KKZ}$ index was reported to have negative relationship with bank competition in the study conducted by Anginer (2014). The study by Mirzae (2014) using the case of 146 banks during the period of 1999-2011 found that contestability and institutional factors were important for measuring bank competition in less developed countries whereas inter industry variables were more relevant to study the banking competition in developed countries.

\subsubsection{Macro-economic condition variables}

Macro-economic condition variables include GDP per capita, real annual GDP growth and inflation rate. The importance of the current variables can be seen in the review of banking literature which shows the evidence for increasing importance of bank growth in relation to economic growth (Karman et, al 2016; Rashid et al, 2015). Many previous studies have been conducted in order to analyze the relationship between bank competition and economic growth (Schaek, et, al 2010). Previous literature in the same sphere provides support for the negative relationship between bank competition and economic growth. Bank competition is reported to increase economic growth in perfect capital markets. This is done through reducing prices and wide availability of the credit. Therefore, with the help of market power the availability of asymmetric information enables to get rid of market imperfections and accelerates economic growth. According to Gonzales, (2016) bank's incentives may increase over time to invest more for acquiring necessary information as a result of ongoing relationship with the bank customer. Previous research shows that there is a positive influence of bank market power on economic growth (Fernandez et al, 2016; Yang and Shao, 2016). This is mainly observed in more financially dependent markets.

Table 2: Variables explaining bank competition

\begin{tabular}{|l|}
\hline Market structure variables \\
Bank concentration ratios, \\
Number of banks, \\
Foreign ownership of banks, \\
State owned banks \\
\hline Contestability variables: \\
Activity restriction \\
Financial conglomerate \\
Limit on foreign bank \\
Entry requirement \\
Fraction denied \\
\hline Inter-industry variables: \\
Insurance \\
Market capitalization \\
Stock market efficiency \\
\hline Institutional variables: \\
Property rights \\
KKZ index \\
\hline Macro-economic conditions \\
GDP per capital, \\
Real annual GDP growth, \\
Inflation rate \\
\hline
\end{tabular}

The research conducted by Claessens and Leaven (2004) studied the impact of bank regulations and institutional variables on bank competitiveness. By analysing the data collected from 50 countries, they identified those contestability variables including activity restrictions and financial conglomerate had substantial influence on bank competition compared to market structure variables. 
Similar to the findings reported by Claeesens and Laven, Bikker (2007) also found no influence of market structure variables, particularly concentration on bank competition using the data from 101 countries. Particularly, Bikker (2007) mentioned that the importance of contestability variables, particularly activity restrictions and entry requirement which are more likely to be positively related to bank competition. The positive influence of the other variables including inter-industry and institutional variables has also been mentioned to show positive relationship with bank competition (Thorsten Beck and Jonghe, 2013).

\section{Conclusion}

Scientists believe that competition is an essential for social well-being and economic development of the country. However, competition should not be too strict and severe to the extent that will negatively impact on innovativeness and openness for new opportunities. Literature of the banking shows that factors contributing to the banking competition are not directly measured. Thus, according to the previous literature it can be stated that the number of banks in the market, their concentration and their relative size should be defined in order to simplify the process of measuring bank competition. However, possible entrance of new banks and their efficiency can also be considered as one of the factors measuring competition. Moreover, the literature studying banking competition consists of different variables including market structure variables, contestability, inter-industry variables and institutional variables. Many scholars argue (Panzar, 1987) that banking industry should be carefully analyzed and reshaped due to the recent financial crisis.

This paper has critically analyzed and reviewed different studies in the field of bank competition. Competition is considered to be crucial in many spheres, particularly in banking sphere as well. Financial sector has become more liberalized and modernized as a result of advances in new information communication technologies. The significant changes that have taken place motivated bank experts and scholars to make further research in order to have better understanding of potential determinants of bank competition. Review of the literature is focused on identifying the importance of market structure variables, industrial variables, contestability variables and institutional variables and their direct influence on bank competition. The identification and analyzes of these variables are critical to understand the main schools of thought including bank fragility and competition stability theories. Review of literature included in this paper provides evidence for the popular usage of main measurements of bank competition including HHI index, Lerner index, Boone indicator and H-statistic. The usage of these measurements is directly related to potential variables of bank competition such as market structure variables. Studies showed that banking competition is intense mainly in the developed countries. However, more attention should be paid to understand and measure the bank competition in developing countries as well. In this regard, the value of potential determinants or variables of bank competition will be very important since each market is different in terms of their concentration, number of banks, macro-economic condition and inter industry conditions.

Due to the different economic situation and market condition in different countries, it is difficult to identify the exact determinants of banking competition. Considering antitrust regulation, decreasing obstacles to foreign investments, and no restrictions for larger banks makes competition even intense. Most of the countries are still observing the decrease in their rates of bank competition despite significant improvements in many spheres. Therefore, it is recommended that future research should include the empirical analysis in order to determine the real value of bank competition.

\section{References}

- $\quad$ Abedifar, P., Molyneux, P., Tarazi, A., (2014). Non-Interest Income Activities and Bank Lending, Working Paper.

- $\quad$ Allen, F., Gale, D., (2004). Competition and financial stability. J. Money Credit Bank. 36, 453-480, CrossRef

- Andrievskaya, A, and Semenov, M (2016) Does banking system transparency enhance bank competition?Cross-country evidence. Journal of Financial Stability 23 (2016) 33-50, $\underline{\text { CrossRef }}$

- $\quad$ Anginer, D., Demirguc-Kunt, A., Zhu, M., (2014). How does competition affect bank systemic risk? Journal of Financial Intermediation 23, 1-26, CrossRef

- $\quad$ Apergis, N., (2015) Competition in the banking sector: New evidence from a panel of emerging market economies and the financial crisis. Emerging Markets Review 25, 154-162, $\underline{\text { CrossRef }}$

- Barbosa K, Rocha B, Salazar, F., (2015) Assessing competition in the banking industry: A multi-product approach Journal of Banking \& Finance 50 340-362, $\underline{\text { CrossRef }}$ 
- $\quad$ Beck, T., De Jonghe, O., Schepens, G., (2013). Bank competition and stability: cross-country heterogeneity. J. Financ. Intermed. 22,218-244, CrossRef

- $\quad$ Bikker, J.A. \& De Dreu, J. (2007). Operating Costs of Pension Schemes. In: Steenbeek, O. \& Van der Lecq, S.G. (eds), Costs and Benefits of Collective Pension Systems. Springer: Berlin, Heidelberg, New York, 51-74, CrossRef

- Bolta, W., Humphrey, D., (2015). A frontier measure of U.S. banking competition. European Journal of Operational Research 246, 450-461, CrossRef

- Bolta, W., Humphrey, D., (2015). Assessing bank competition for consumer loans. Journal of Banking \& Finance 61, 12714, CrossRef

- Boone, J., (2008). Competition: theoretical parameterizations and empirical measures. J. Inst. Theor. Econ. 164, 587-611, $\underline{\text { CrossRef }}$

- $\quad$ Boone, J., Griffith, R., Harrison, R., (2005). Measuring competition. AIM Research WP. Series.

- $\quad$ Boyd, J.H., De Nicolo, G., (2005). The theory of bank risk-taking and competition revisited. Journal of Finance 60, 13291343, $\underline{\text { CrossRef }}$

- $\quad$ Braunstein, S. \& Welch, C. (2002). Financial Literacy: An Overview of Practice, Research, and Policy. Federal Reserve Bulletin, 88 (11), November, 445-457.

- $\quad$ Claessens, S., Laeven, L., (2004). What drives bank competition? Some international evidence. Journal of Money, Credit andBanking 36 (3), 563-583, CrossRef

- Delis, M.D., (2012). Competitive conditions in the Central and Eastern European banking systems. Omega 38, 268-274, CrossRef

- Diallo, B (2015). Bank competition and crises revisited: New results. Economics Letters 129 (2015) 81-86, CrossRef

- Diallo, B. (2015) Bank competition and crises revisited: New results. Economics Letters 129,81-86, CrossRef

- Fernándeza, A, Gonzálezb, F., Suáreza, N (2016) Banking stability, competition, and economic volatility Journal of Financial Stability 22 101-120, $\underline{\text { CrossRef }}$

- Fungacova Z, Solanko, L, Weill, L (2014) Does competition influence the bank lending channel in the euro area? Journal of Banking \& Finance 49 (2014) 356-366, $\underline{\text { CrossRef }}$

- Gonzales, F (2016). Creditor rights, bank competition, and corporate investment during the global financial crisis. Journal of Corporate Finance 37 , 249-270, CrossRef

- Jappelli, T. (1993). Banking Competition in Southern Italy: A Review of Recent Literature. Studi Economici, 49, 47-60.

- Jeon, J, Lim, K (2013) Bank competition and financial stability: A comparison of commercial banks and

- Karman, H., Malik, Sh., Butt, H., Hamza M., , Afzal, U., Maqbool Sh., (2016) Risk Premium and Its Effect on Bank's Non-Performing Loans International Journal of Innovation and Economic Development Volume 1, Issue 6

- Kasman, S., and Kasman, A., (2015) Bank competition, concentration and financial stability in the Turkish banking industry. Economic Systems 39, 502-517, CrossRef

- $\quad$ Keeley, M., (1990). Deposit insurance, risk, and market power in banking. American Economic Review 80, 1183-1200.

- Koetter, M., Kolari, J., Spierdijk, L., (2012). Enjoying the quiet life under deregulation? Evidence from adjusted lerner indices for U.S. Banks. Review of Economics and Statistics 94, 462-480, CrossRef

- Laeven, L., Valencia, F., (2013). Systemic banking crises database. IMF Econ. Rev. 61, 225-270, CrossRef

- Leon, F (2015) Does bank competition alleviates credit constraints in developing countries? Journal of Banking \& Finance 57 (2015) 130-142, $\underline{\text { CrossRef }}$

- Leon, F (2015) Does the expansion of regional cross-border banks affect competition in Africa? Indirect evidence. Research in International Business and Finance 37 (2016) 66-77

- Liikanen, E. (2012). High-level expert group on reforming the structure of the EU banking sector, Brussels, 2. 2012

- Martinez-Miera, D., Repullo, R., (2010). Does competition reduce the risk of bank failure? Rev. Financ. Stud. 23, 36383664, $\underline{\text { CrossRef }}$

- $\quad$ Milbourn, T., Boot, A., Thakor, A., (1999). Megamergers and expanded scope: theories of bank size and activity diversity. Journal of Banking and Finance 23, 195-214, CrossRef

- Mirzaei, T (2014), What are the driving forces of bank competition across different income groups of countries? Journal of International Financial Markets, Institutions \& Money 32, p. 38-71, CrossRef

- Mulyaningsiha, T., Dalyb, A and Mirantica, R (2015) Foreign participation and banking competition: Evidence fromthe Indonesian banking industry Faculty Journal of Financial Stability $1970-82$, CrossRef

- Panzar, J., Rosse, J., (1987). Testing for monopoly equilibrium. The Journal of Industrial Economics 35, 443-456, CrossRef

- $\quad$ Panzar, J., Rosse, J., 1987. Testing for monoply equilibrium. J. Ind. Econ. 35, 443-456, CrossRef

- Panzar, J.C., Rosse, J.N., (1987). Testing for "monopoly" equilibrium. J. Ind. Econ. 35, 443-456, CrossRef

- Rashid, F, John, M, Consolatta, N, Stephen, S (2015). Impact of microfinance institutions on economic empowerment of women entrepreneurs in developing countries International Journal of Management Science and Business Administration Volume 1, Issue 10, Pages $45-55$

- Sääskilahti, J (2016) Local bank competition and small business lending after the onset of the financial crisis Journal of Banking \& Finance 69 37-51, $\underline{\text { CrossRef }}$ 
- Schaeck, K., Cihak, M., (2010). Competition, Efficiency, and Soundness in Banking: An Industrial Organization Perspective, European Banking Centre Discussion Paper No. 2010-20S.

- Tabacco, G (2013) A new way to assess banking competition Economics Letters 121 167-169, CrossRef

- Thorsten Beck, T., Jonghe, O.D., (2013). Bank competition and stability: cross-country heterogeneity. Journal of Financial Inter-mediation 22, 218-244, CrossRef

- $\quad$ Turk-Ariss, R., (2009). Competitive behaviour in Middle East and North Africa banking systems. Quarterly Review of Economics and Finance 49, 693-710, $\underline{\text { CrossRef }}$

- Weill, L (2013) Bank competition in the EU: How has it evolved? Int. Fin. Markets, Inst. and Money 26 (2013) 100-112, CrossRef

- Yang J, Shao, H (2016) Impact of bank competition on the bank lending channel of monetary transmission: Evidence from China. International Review of Economics and Finance 43 (2016) 468-481, $\underline{\text { CrossRef }}$ 